\title{
ABSORPTION OF DISPOSITION IN ARCHAIC INDIAN CRAFT AND ITS COMMUNAL PURPOSE
}

\section{Shailesh Shukla}

Department Of History, Lucknow University , India

\section{Abhimanyu Singh}

Department Of History, Patna University , India

\section{ABSTRACT}

This article attempts to clarify the perspective as contained in the old Indian craftsmanship where disposition and human life are so weaved with one another that they become the fundamental piece of the other and this comprehensiveness gets back the point that they are not totally unrelated as is considered in present day times. Old Indian craftsmanship represents this coordinated methodology and one may discover the absorption of disposition in each structure considered and portrayed in that.

KEYWORDS:- Prakṛti, pañca-tattva, disposition, Gañgā-Yamunā, Indian workmanship

\section{INTRODUCTION}

Disposition for example Prakrti is inescapable and supreme and, thus, Indian religion and reasoning from the Vedic occasions, discussed the disposition and its significance Agrawal, V.S. 1964: 1-29; Ray: 1975. The vegetation alongside water, fire, earth, sky and wind pañca tattvafive antiquated components involve a generous and incorporated samprkta place in the complete plenty of Indian Craft Coomaraswamy, A.K. 1996: 1-29 . Truth be told, Indian workmanship is by all accounts the incorporated visual appearance of human and non-human instinct structures. Our antiquated sacred writings are brimming with such references which show not just the significance of earth, tree, water, creature, plant for our endurance yet in addition make them holy objects of love. Their holiness and, along these lines, respect in the psyche and he craft of individuals, normally prevented them from making any harm the Disposition and furthermore supported them for its safeguarding for the endurance and food of the whole humankind 


\section{Discussion}

In an uncommon outside huge stone cut board at Mahābalipuram Tamilnadu, I could see both the sign of time and presence of disposition. This splendid Gañgāvatarana board of Pallava period is datable to seventh century CE Sivaramamurti, C. 1995: 24-28 . In the focal point of the bluff there is a hole showing nāga figures which are streaming lower to recommend plunge of Gangā on the earth. On ground level, on its correct bank two figures are appeared of which one is conveying water-pitcher kalaśa having Gañgā jala while other one is crushing water from his long hair in the wake of scrubbing down in the Gangā. Notwithstanding, two other male figures are appeared in two changed offers of Sūrya namaskāra. One is in namaskāra mudrā while the other one is having both the hands being raised over the head with open palms confronting sky and their fingers contacting one another. These figures unmistakably recommend that this Gangāvatarana board addresses the typical strict exercises on the bank of Gangā toward the beginning of the day hours. It has additionally normal renderings of the figures of elephants in bunch with infant elephants, deer and tiger to give sway befitting the event of retribution of Bhagirath and plummet of Gangā on the earthGanggāvataraṇa

\section{Conclusion}

Indian workmanship, along these lines, in the entirety of its size and indications has consistently been eco-accommodating assimilating the components of disposition verdure and fauna for giving explicit significance and personality to the structures in models/symbols. Additionally, disposition has consistently embellished the models and given important scenery. We may take a gander at the plenty of Indian Craft from the view point that it addresses the life and thought about the past to fill in as the ideal model for the present and, thusly, all such visual models become important for us all today. Indian workmanship totally gives lasting directive for us all today to live with disposition and become eco-accommodating to guarantee our own reality.

\section{REFRENCES}

1. chaparwal k.c. 1966. Indian Art. Varanasi.

2. r. swami, g. h. 1996 (republish). Change of Disposition in Art. New Delhi.

3. Epigraphia Indica (EI). Vol. 7.

4. das.niranjana 1973. An Approach to Indian Art. Chandigarh.

5. upkar, j. k. 1994 (reproduce). Select Inscriptions. Vol. I. Delhi.

6. narayna, krishnmurti 1993. A few Aspects of Indian Culture. New Delhi. 